Open Access

Martine Robbeets*

\title{
The development of finiteness in the Transeurasian languages
}

DOI 10.1515/ling-2017-0004

\begin{abstract}
Nonfinite verb forms can gradually acquire morphological and syntactic properties of finiteness. Across the languages of the world, such developments can follow various pathways with various results. In this article, I first discuss the four major pathways mechanisms for developing finite function on formerly nonfinite forms. Next, I argue that the Transeurasian languages (i. e., Japanese, Korean, Tungusic, Mongolic, and Turkic languages) share a common mechanism. Historical reconstruction indicates that these languages all show the tendency to reanalyze directly a nonfinite verb form as a finite one, without the omission of a specific matrix verb. I refer to this tendency as "indirect insubordination". I argue that the recurrence of indirect insubordination on formally related suffixes can be taken as an indication of common ancestorship.
\end{abstract}

Keywords: finiteness, indirect insubordination, genealogical relationship, Transeurasian, Japanese, Korean, Tungusic languages, Mongolic languages, Turkic languages

\section{Mechanisms of finitization}

The languages of the world use a variety of mechanisms for developing finite function on formerly nonfinite forms, a process that will be referred to as “finitization”. Finiteness, as pointed out by Trask (1993: 103-104), Nedjalkov (1995: 97), Givón (2001: 25-26), Bisang (2001), Malchukov (2006), Nikolaeva (2007: 1-7) and Mithun (2016) can be understood in morphological as well as in syntactic terms. On the morphological side, finite forms typically carry the maximum marking for such categories as tense, aspect, modality, and agreement permitted in the language. On the syntactic side, finite forms have the capacity to function as the only predicate of an independent clause. In

*Corresponding author: Martine Robbeets, Max Planck Institute for the Science of Human History, Kahlaische Strasse 10, 07745 Jena, Germany, E-mail: robbeets@shh.mpg.de 
contrast, verbal nouns, participles, and converbs are nonfinite verb forms that generally display less marking of inflectional categories and whose prototypical function is to mark argument, adnominal and adverbial subordination respectively. ${ }^{1}$ Nonfinite verb forms, however, can gradually acquire morphological and syntactic properties of finiteness. Such developments can follow various pathways with various results. In this section, I discuss the four major pathways by which nonfinite verb forms can acquire properties of finiteness, providing illustrations from Ket, Russian, Sizang, Japanese, and Barbareño Chumash.

One common strategy is to reduce the matrix predicate to an affix or a particle on the former nonfinite verb form. In Example (1), for instance, the matrix verb bimbata 'it is audible' in Ket is reduced to a present suffix -beta -bata on verbs expressing sound production, whereas the past verb bil'ata 'it was audible' has evolved into the past suffix -bileta bil'ata (Malchukov 2013: 196-197). According to Werner (1997: 278-279) these finite constructions derive from the contraction of a verbal noun taking possessive agreement ('my whistling') and the matrix verb ('it is/was audible'). As, the matrix verb is contracted but not deleted, it contributes to the resultant finite form.

(1) Reduction of finite verb to affix in Ket

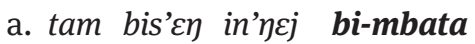

PT what sound be.audible-PRS

'a certain sound is audible'

(Werner 1997: 170)

b. p-kutal'ej-beta

1SG.POSS-whistle-PRS

'I whistle'

(Werner 1997: 187)

Alternatively, a construction consisting of a nonfinite verb form plus finite copula can be reanalyzed as a verbal predicate, whereby the copula may be subsequently

\footnotetext{
1 Since this paper deals with morphological reconstruction, I focus on finiteness as the property of the verbal form rather than the property of the clause. Defining the finite verb as carrying the maximum marking for such categories as tense, aspect, modality and agreement permitted in the language, my understanding of finiteness is admittedly simplified. An anonymous reviewer justly remarked that such an inflectional approach to finiteness is too narrow to have a universal application. Nevertheless, the fact that dependent clauses tend to display less inflectional marking than independent clauses within a certain language can be seen as a crosslinguistic tendency motivated by the pressure for economic expression.
} 
lost. A classic example is given in (2a)-(2b), where in Old Russian a nominal construction plus copula 'the land is the one that came about' is reanalyzed as a verbal predicate 'the land came about' and then, later in Russian, the copula is dropped. Although the copula is entirely lost in the contemporary Russian example in (2b), the ending $-l-a$ reflects predicate material from the finite verb form because the former nonfinite verb form was reanalyzed as a periphrastic perfect verbal predicate before the copula was dropped.

(2) Verbalization of nonfinite verb form plus finite copula in Russian
a. OR rusk-aja zemlja sta-l-a es-tĭ Russian-F.SG land come.about-PERF.PCP-F.SG be-3SG 'The Russian land has come to exist' (Tale of bygone years, The Laurentian codex, 1377)
b. Rus. ty spa-l-a you sleep-PST-F.SG
'You slept'

The loss of the copula may pass through an intermediate stage in which the former copula grammaticalizes to a sentence-final particle, as is often seen in the Tibeto-Burman languages (DeLancey 2011). The Sizang (Northern Chin) finite clause in (3b), for instance, can be derived from a nominalized construction because the clitic used for verb agreement is a possessive proclitic, also used with nouns as in Example (3a). The equational copula hi of the original construction has left a trace in the homophonous final particle.

(3) verbalization of nonfinite verb form plus finite copula in Sizang
a. kâ mei
1POSS tail
'my tail'

(DeLancey 2011: 350)

b. ká pài: hî:

1POSS go PT

'I go /went'

(DeLancey 2011: 350)

A third strategy involves the entire omission of the matrix predicate and the maintenance of the complement, which then takes on the function of the missing matrix as in Example (4) from Japanese where the dependent conditional clause 'if you gave it a try' takes on the propositional meaning of the matrix predicate. This is the type to which Evans (2007: 367) applies the term 
"insubordination", defining it as "the conventionalized main clause use of what, on prima facie grounds, appear to be formally subordinate clauses.”

(4) omission of verbal predicate in Japanese
a. yatte mi-tara dou desu-ka
do-CONV see-COND how be-Q
b. yatte mi-tara?
do-CONV see-COND
'Why don't you give it a try?'

Finally, a nonfinite verb form may be directly reanalyzed as a finite one, without the omission of a specific matrix verb, as in Example (5) from Barbareño Chumash (Mithun 2016). According to Mithun, the prefix al- began as a derivational nominalizer applied to verb stems to create noun stems, e. g., 'be hot' $\rightarrow$ 'sun' in (5a). As illustrated in (5b), it was then extended to the clause level to create participant nominalizations, used to refer to persons, animals, objects, locations, times an manners, e. g., 'he did it' $\rightarrow$ 'the past way of doing'. Such nominalized clauses could be juxtaposed to other nominals to add supplementary information, much like relative clauses as in 'a sick one, a person' $\rightarrow$ 'a sick person' in (5c). This relative clause with al- has been extended on step further, to mark full, syntactically independent sentences which add supplementary information in discourse such as background, setting, commentary, general principles, asides, explanation, evaluation, etc., as illustrated in (5d). These sentences do not display the morphological marking of syntactic nominals, such as the dependency clitic $h i=$ or the article $l=$.

Mithun (2008) argues that markers of dependency are simply extended from the level of syntax to the level of discourse and that ellipsis was not involved in the process. The general statement about marihuana in (5d), for instance, opened a story about a Mexican worker who smoked marihuana. The subsequent narrative was mainly in finite sentences without al- marking. Although the statement can be interpreted as subordinated to the rest of the discourse, the pitch contour reflects its status as a syntactically independent sentence. The alconstruction has thus been extended in scope from marking syntactically dependent clauses that contribute supplementary information to the sentence, to marking independent sentences that contribute supplementary information to the discourse. Comparisons with other languages in the family confirm that the direction of development was indeed in this direction, from the lexical to the syntactic to the discourse level. More examples of direct reanalysis can be found in Dyirbal, Kayardild (Dixon 1972: 104; Evans 2007: 408-409), Navajo, and Central Alaskan Yup'ik (Mithun 2008). 
(5) Direct reanalysis of nonfinite verb form in Barbareño Chumash

a. Lexical nominalization išaw 'be hot, (sun) to shine' $\rightarrow$ Pal-išaw 'sun, day'

b. Clausal nominalization

K-e-ča'min Pal-asnes-waš

1-NEG-know NML-do-PST

'I don't know how he did it'

c. Relative clause

$\begin{array}{ll}H i=l=\text { ?al-yuxpan } & h i=l=k u \\ \mathrm{DEP}=\mathrm{ART}=\mathrm{NML}-\text { be.sick } & \mathrm{DEP}=\mathrm{ART}=\text { person }\end{array}$

'A sick person'

d. Independent sentence

No'no Pal-Pitaxmayšis $h i=h e ?=l=$ maliwana .

very NML-be.wonderful $\mathrm{DEP}=\mathrm{PROX}=\mathrm{ART}=$ marihuana

'Marihuana is really wonderful.'

(Mithun 2016)

The examples in (1), (2) and (3) can be explicitly excluded as instances of insubordination" because here the matrix verb contributes to the resultant finite form. This is in line with Evans' (2007: 384) requirement that "the resultant construction draws its material from only the old subordinate clause". Indeed, in the Ket example in (1b) the original finite verb is contracted but not deleted, in the Russian example in (2b) the original copula was lost only after reanalysis as a verbal predicate and in the Sizang example in (3b) the original copula is preserved as a final particle.

Examples like (5) however, are not excluded by Evans' requirement and they can therefore be regarded as instances of "insubordination", even if they do not involve the ellipsis of a matrix verb (Evans 2007: 408-409). Note that Malchukov (2013) proposes distinguishing between instances like (4), which he subsumes under the term "insubordination proper" and (2) and (3), which he refers to as "verbalization", but contrary to Evans' and my approach, he does not include (5) as a possible insubordination scenario. Similarly, Bisang (2016: 31) objects to subsuming the development of nominalized forms to finite forms under "insubordination", arguing, "they should at least be separated as a special subpart of insubordination if they are not completely dissociated from that term". In the present approach, however, a distinction is made between nominalized forms that are directly reanalyzed as finite forms as in (5) and nominalized forms that are reanalyzed as verbal predicates through the use of a copula as in (2) and (3). The former are separated as a special subpart 
of insubordination, i. e., "direct insubordination", whereas the latter are kept completely dissociated from that term. This distinction is highly relevant for the present discussion because it is exactly the mechanism of direct reanalysis illustrated in (5) that is one of the driving forces of morphosyntactic change in the Transeurasian languages.

Although the purpose of this article is to present a historical reconstruction of finitization processes in the Transeurasian languages, this does not preclude paying attention to syntactic developments, since finiteness is not a matter of mere morphology. In this article, I will argue that these languages show a recurrent tendency for deverbal noun suffixes to grammaticalize, first, to markers of syntactically dependent complement or relative clauses and then, directly to markers of fully independent sentences. In Sections 2 and 3, I will discuss this development in two sets of cognate suffixes, originating from the common Transeurasian deverbal noun suffixes ${ }^{\star}$ - $r A$ and ${ }^{\star}-m A$. In Section 4 , I will propose that the prototypical process for developing finiteness in the Transeurasian languages is "direct insubordination", distinguishing it from the verbalization of nonfinite verb form plus finite copula, which is present in some Paleo-Siberian languages and recurrent in Sinitic and Tibeto-Burman. Finally, I will describe "direct insubordination" as an inherited force, decisive in shaping and re-shaping Transeurasian grammar.

\section{2 pTEA *-rA}

\section{1 pJ *-(wo-)ra}

The deverbal noun suffix $\mathrm{pJ}^{\star}{ }^{\star}$-ra can be reconstructed as a suffix that derived nominal and adnominal forms from verbal adjectives such as in OJ $a k a$ - 'to be red' $\rightarrow$ akara 'red', usu- 'to be fine' $\rightarrow$ usura 'fine', uma- 'to be tasty' $\rightarrow$ umara 'tasty', $y_{2^{-}}$'to be good' $\rightarrow \mathrm{yo}_{2} r a$ 'good', sakasi- 'to be wise' $\rightarrow$ sakasira 'wisdom', kanasi- 'to be sad' $\rightarrow$ kanasira 'sadness', EMJ be- necessitive $\rightarrow$ bera nar- necessitive, etc.; see (6a) (Antonov 2007: 102, 111, 128-132, 153, 160, 196, Vovin 2009: 436-440). ${ }^{2}$ Unless OJ tatara 3.4 'foot-bellows' can be derived from OJ tat- B 'stand' (< ${ }^{\star}$ tata-) and this suffix, there are no indications of deverbal derivation.

2 The vowel notation with upper case A refers to the vowel harmony archphonemes Old Turkic a/e, Written Mongolian a/e, Manchu, Evenki, Udehe a / o / e and Even/ Nanai a/e. In protoTranseurasian, it refers to the vowel harmonic alternation a/ ə. See Robbeets (2015: 125-126) for the reconstruction of RTR vowel harmony in proto-Transeurasian. 
Clausal (ad)nominalization makes use of a suffix $\mathrm{pJ}{ }^{\star}$-oro reflected as -uru/-ru /-u in Old Japanese and as ${ }^{\star}$-uru /-ru in the Ryukyuan languages, which may go back to a complex form $\mathrm{pJ}{ }^{\star} w o-r a$ consisting of a copula ${ }^{\star} w o$ - and the deverbal noun suffix ${ }^{*}$-ra (Robbeets 2015: 339-346). This is illustrated by the Old Japanese complement clause in (6b) and the relative clause in $(6 \mathrm{c})$.

Although the standard use of this suffix is adnominal, it can be used as a finite form marking independent sentences in both Old Japanese (see (6d)) and the Ryukyuan languages. In such cases, the insubordinated form signals the evaluative nature of the proposition and it may be accompanied by focus particles specifying the exact nature of the speaker's reaction to such as question, exclamation, confirmation, or explanation, etc., a phenomenon known as kakari-musubi in Japanese.

(6) Reflexes of the deverbal noun suffix pJ *-ra in Western Old Japanese

a. Lexical (ad)nominalization

aka-ra tatibana

be.red-NML mandarin-oranges

'red mandarin-oranges'

(MYS 28: 4060))

b. Clausal nominalization

punapi to $_{2}$-wo $\mathrm{mi}_{1}$-ru-ga $\mathrm{to}_{2} \mathrm{mo}_{2} \mathrm{Si}$-sa

boat.people-ACC see-NML-GEN enviable-NML

'it is enviable to see the boat-people'

(MYS 15: 3658; Wrona 2008: 206)

C. Relative clause

op-i $i_{1}-k$-uru $\quad \mathrm{mo}_{2} \mathrm{no}_{2}$

pursue-CONV-come-ADN thing

'the things that pursue [us]'

(MYS 5: 804; Vovin 2009: 613)

d. Independent sentence

ide ika-ni kokodaku kop-uru

Oh why-DAT so.much love-FIN

'Oh, why do I love her this much?'

(MYS 12: 2889; Wrona 2008: 206)

The examples in (6) suggest that $\mathrm{pJ}^{{ }^{*}}$-ra began as a derivational nominalizer applied to verbal adjective stems to create noun stems: 'be sad' $\rightarrow$ 'sadness'. In Old Japanese - as in most Transeurasian languages - noun stems could be juxtaposed to other nominals to add supplementary information, thus 
functioning as property nouns, i. e., nominally encoded adjectives: 'be red' $\rightarrow$ 'red (oranges)'. Whereas lexical nouns were derived by adding the suffix *-ra directly to verbal stems, clausal nominalizations incorporated the copula * $w o$ - 'to be'. The nominalized auxiliary *wo-ra fused into a suffix and became the clausal (ad)nominalizer OJ -uru, which marked complement clauses and relative clauses in Old Japanese. The relative clauses with -uru developed one step further to mark syntactically independent sentences which added supplementary information in discourse such as question, exclamation, confirmation, explanation.

\section{$2.2 \mathrm{pK} *-($ wo-)l}

The clausal (ad)nominalizer $\mathrm{pK}^{\star}-l$ can be reconstructed on the basis of $\mathrm{K}-(u) l$, MK $-(\cdot u / o) l$. The contemporary Korean adnominalizer $\mathrm{K}-(u) l$ is usually called "prospective" because reference to the future is the most common meaning today. In Middle Korean, however, MK $-(\cdot u / o) l$ is the default imperfective adnominalizer, in essence time neutral (Martin 2002: 376). While the standard function of MK $-(\cdot u / o) l$ is nominal modification as in (7c), it may also be used for complementation, preceding case suffixes, such as the Middle Korean genitive marker $s$ in (7b). The so-called "modulator" $\mathrm{MK} \cdot \cdot w^{u} / o-$, which has been derived from an original copula $\mathrm{pK}$ * $w o$ - 'to be' by Martin (1996: 13, 83, 2006: 222); sometimes appears before $\mathrm{MK}-(\cdot u / o) l$. In case the modified noun is semantically the object of the adnominalized verb, as in Example (7d), the modulator is always added; otherwise, the modulator is not obligatory. There are few examples left of lexical nominalization reflecting $\mathrm{pK}{ }^{\star}-l$ such as MK $k u c h$ - 'to stop' $\rightarrow k u \cdot c h u l$ 'cessation' in (7a), but it is not unlikely that originally, lexical nouns were derived with $\mathrm{pK}{ }^{\star}-l$, while clausal nominalization needed the incorporation of the copula $\mathrm{pK}{ }^{\star} w o-$, which would be in line with the behavior of the nominalizer $\mathrm{pK}^{\star}-m$ in Section 3.2.

As a finite marker the suffix $\mathrm{pK}^{\star}-l$ precedes the interrogative marker MK .kwo expressing rhetorical, exclamatory or quoted questions (Martin 1992: 667) and it is incorporated in the ending of explicit statement $\mathrm{K}-u l i$, MK $-(\cdot u / o) \cdot l i$ (Martin 1992: 856-857) and in the subjunctive attentive ending $\mathrm{K}-(u) l a$, MK $-(\cdot u /$ o).la (Martin 1992: 851, 2002: 378-379), as illustrated in (7e). Whereas the subjunctive attentive is morphologically segmentable into the imperfective adnominalizer and the vocative particle $a$, which usually follows nouns (e. g., K palk-un tal-a [shine-ADN moon-VOC] 'Oh shining moon!'), the explicit ending derives from the adnominalizer and a bound noun MK $i$ 'fact (that); that (which)'. 
(7) Reflexes of the deverbal nominalizer $\mathrm{pK}^{\star}$ - $l$ in Middle Korean

a. Lexical nominalization

ku.ch-ul-s $\quad$ sus

stop-NML-GEN time

'a period of cessation'

(1459 Wel 7:58b; Martin 1992: 873)

b. Clausal nominalization

"se twoy tu-li-l-s HHWA-PPYENG-•ul nwo-·khwo

three measure contain-NML-GEN vase-ACC place-CONV

'Placing a vase with a capacity of three cupfuls'

(1459 Wel 10: 119 a; Martin 1992: 873)

c. Relative clause

wo-l ce $k$-uy $\cdot k i l h-i \quad$ "ki-two-'ta

come-ADN time-DAT way-NOM be.long-EMO-FIN

'The way is long when coming [here]'

(1481 Twusi 17: 17a; Martin 2002: 376)

d. Clausal object-adnominalization

$\begin{array}{lll}\text { ccywung-soyng-oy } & \text { nip-wu-l } & \text { wos } \\ \text { common.people-NOM } & \text { wear-MOD-ADN } & \text { clothing }\end{array}$

'clothes that the common people wear'

(1459 Wel 8: 65; Lee and Ramsey 2011: 206)

e. Independent sentence

QILQ-SIM-•u•lwo kwoyGwoy ho-·l-a

wholehearted-ADV silence do-FIN-VOC

'Be utterly quiet!'

(1464 Kumkang 12a; Martin 1992: 851)

The examples in (7) suggest that $\mathrm{pK}{ }^{\star}-l$ began as a derivational nominalizer applied to verb stems to create nouns: 'to stop' $\rightarrow$ 'cessation'. Noun stems expressing properties could be juxtaposed to other nominals to add supplementary information. Whereas lexical nouns were derived by adding the suffix *- $l$ directly to verbal stems, clausal nominalizations incorporated the copula *wo- 'to be'. The relative clauses marked with $\mathrm{pK}{ }^{\star_{-}}$(wo)-l developed one step further to mark syntactically independent sentences which added supplementary information in discourse such as question, exclamation, confirmation and explanation. As such, the deverbal (ad)nominalizer $\mathrm{pK}^{\star}{ }_{-} l$ does not only correspond to $\mathrm{pJ}^{\star}{ }^{\star}$-ra in form and function, but the correlations also involve the incorporation of a cognate copula ${ }^{\star} w o$ - 'to be' in clausal (ad) nominalization and the further development to finite use in particular discourse contexts. 


\section{$2.3 \mathrm{pTg}$ *-rA}

The deverbal noun suffix $\mathrm{pTg}{ }^{\star}-r A$ can be reconstructed as a suffix that derived nominal and adnominal forms from verb stems such as Even da:l- 'to be sweet, pleasant, light' $\rightarrow$ dalra 'sweet, tasty', Even eden- 'to be windy, to blow (of wind)' $\rightarrow$ edenre 'windy', Even eman- 'to snow, fall (of snow)' $\rightarrow$ emanra 'snow, snow-' and Evenki langa- 'to break a tooth' $\rightarrow$ langara 'toothless' (Nedjalkov 1997: 305); see (8a).

The suffix is also used for clausal (ad)nominalization, as illustrated by the Manchu complement clause in (8b) and the relative clause in (8c). In the other Tungusic languages more recent deverbal noun suffixes of the shape pTg ${ }^{*}$-ri: have replaced the old ones on ${ }^{*}$-ra in complement and relative clauses. The forms reflecting $\mathrm{pTg}^{{ }^{*}}-r A$ are maintained however in the finite paradigms throughout all Tungusic languages, including the Manchu example in (8d).

(8) Reflexes of the deverbal noun suffix pTg ${ }^{\star}-r A$ in Tungusic

a. Lexical (ad)nominalization in Even

eman-ra beike:n

snow-NML doll

'a snowman'

b. Clausal nominalization in Manchu

mama-de ala-ra-de, mama hendu-me...

old.woman-DAT tell-NML-DAT old.woman say-CONV

'When [he] tells [it] to the old woman, the old woman says: “...”

(Gorelova 2002: 257)

c. Relative clause in Manchu

bargiyata-ra niyalma

protect-ADN people

'people who protect [him]'

(Gorelova 2002: 485)

d. Independent sentence in Manchu

si nene-me isinji-ci uthai sin-de bu-re

you be.first-CONV come-CONV at.once you-DAT give-FIN

'If you come first, I shall give [it] to you straight away'

(Gorelova 2002: 256)

The examples in (8) suggest that pTg *-ra began as a derivational nominalizer applied to verb stems to create nouns: 'to snow' $\rightarrow$ 'snow'. In Tungusic - as in most Transeurasian languages - noun stems expressing properties could be 
juxtaposed to other nominals: 'to snow' $\rightarrow$ 'snow (man)'. The (ad)nominalizers were then extended to the clause level to mark clausal (ad)nominalization in complement and relative clauses. The relative clauses developed one step further to mark syntactically independent sentences. Initially, these constructions may have added supplementary information, but gradually they generalized into the default indicative ending.

\section{$2.4 \mathrm{pMo}^{*}-\mathrm{r}$}

The deverbal noun suffix pMo ${ }^{\star}-r$ can be reconstructed as a suffix that derived verb stems from nouns in Mongolic. As illustrated in (9a)-(9c), the Written Mongolian and Middle Mongolian suffix $-r$, with the epenthetic vowel $-u-/-\ddot{u}$ - if the stem ended in a consonant, commonly derived deverbal nouns such as MMo. andaqa- 'swear an oath of friendship' $\rightarrow$ andaqar 'oath of friendship', WMo. belčige- 'to pasture, graze (tr.)' $\rightarrow$ belčiger 'pasture, grazing grounds, grass on a pasture' and WMo. irüge- 'bless, pray, wish well (tr. /intr.)' $\rightarrow$ irüger 'prayer, blessing' or deverbal property nouns such as MMo. /WMo. amu- 'to rest, relax; be relieved (intr.)' $\rightarrow$ amur 'peace, rest; easy' and WMo. qusu- 'to scrape, shave (tr.)' $\rightarrow$ qusur 'pointed' (Poppe 1954: 49; Street 1957: 58.)

As illustrated in (9b), there are relics of clausal nominalization in the final converb in $-r A$ that can be derived from ${ }^{\star}$ - $r$ marking a complement clause plus the dative suffix in ${ }^{\star}$ - $A$ and in the preparative converb on -run, which is a compound of ${ }^{{ }^{*}} r$ and the genitive suffix in ${ }^{*_{\text {-un }}}$ (Poppe 1954: 59, 98, 180). Examples of finite use in Mongolic are lacking, but I think that the past tense suffix $-r$ in (9c) in Khitan, a sister language of proto-Mongolic, is related here.

(9) Reflexes of the deverbal noun suffix pMo ${ }^{{ }^{*}}-r$ in Written Mongolian and Khitan

a. Lexical (ad)nominalization in Written Mongolian

amu-r ajil

relax-NML work

'easy work'

b. Clausal nominalization in Written Mongolian

eke-yügen eri-re od-bai

mother-ACC search-CONV go-PST

'He went to find her mother'

(Sárközi 2004: 47) 
c. Independent sentence in Khitan puu giuun shï po-or fu gong shi become-PST.FIN 'He was appointed a fu gong shi' (Kane 2009: 146)

The examples in (9) suggest that pMo ${ }^{{ }^{*}} r$ began as a derivational nominalizer applied to verb stems to create nouns: 'to pray' $\rightarrow$ 'prayer', whereby noun stems expressing properties could be juxtaposed to other nominals: 'to relax' $\rightarrow$ 'easy (work)'. The (ad)nominalizers were then extended to the clause level to mark clausal (ad)nominalization. There is no evidence that these dependent clauses developed one step further to mark syntactically independent sentences in Mongolic proper, but they probably did in the para-Mongolic language of the Khitan. Therefore, I have put the dependency "independent" between brackets in Table 1.

\section{5 pTk *-rV}

The deverbal noun suffix pTk ${ }^{*}-r V$ has a reflex in Old Turkic as a suffix that derived nouns from verb stems. It is formed with - Ar after most simple consonant stems, -Ur or -Ir after diathetic consonants stems and $-y U r$ or $-r$ after vowel stems. In Robbeets (2015: 158-159), I have proposed that the allomorphs - $y U r /-U r$ and -Ar derive from suffix strings in which pTk ${ }^{\star}-r V$ follows the copular verbs ${ }^{\star} u$ - 'to become' and ${ }^{\star} a$ - 'to be', respectively, while the allomorph -Ir would reflect a stem-final -i.

Even if the suffix is not included in Erdal (1991) and is generally regarded in the Turcological literature to be a participle marker (see 10b), it can be understood from derivational pairs such as OTk teg- 'to reach, be worth (intr.)' $\rightarrow$ tegir 'share, value, price', OTk. tug- 'to be born, to rise (of sun) (intr.)' $\rightarrow$ tugar 'sunrise, east' and OTk. yat- 'to lie down (intr.)' $\rightarrow$ yatar /yatur '(something) lying down, invalid' that it had lexicalized as a deverbal nominalizer in old Turkic; see (10a). In Old Turkic, the adnominalizer - $(A) r$, which is known under the label "aorist", is still productive in relative clauses as in (10b), but it is used more often as a finite predicate as in (10c). For a discussion of the Chuvash and Yakut cognates of this suffix, see Robbeets (2015: 359-361).

(10) Reflexes of the deverbal noun suffix pTk ${ }^{*}-r V$ in Old Turkic

a. Lexical nominalization in Old Turkic

tug-ar-din čadan kop-ti.

rise-NML-ABL Scorpio rise-PST

'Scorpio rose from the east'

(Clauson 1972: 471) 
b. Relative clause in Old Turkic

ak-ïp kel-ir sogik suv

flow-CONV come-ADN cold water

'cold water flowing forth (or coming up)'

(Erdal 2004: 284-285)

c. Independent sentence in Old Turkic

Ölüm-tä oz-upan ögir-ä savin-ü yorï-r.

death-ABL escape-CONV rejoice-CONV be.happy-CONV go.on-FIN

'Having been saved from death it happily goes on with its life.'

(Erdal 2004: 325)

The examples in (10) suggest that $\mathrm{pTk}^{\star}{ }^{\star}$ - $\mathrm{A} A$ began as a derivational nominalizer applied to verb stems to create nouns: 'to rise' $\rightarrow$ 'sunrise', whereby noun stems expressing properties could be juxtaposed to other nominals: 'to lie down' $\rightarrow$ '(thing) lying down'. The (ad)nominalizers were then extended to the clause level to mark clausal (ad)nominalization. Relative clauses developed one step further to mark syntactically independent sentences with a present continuous meaning.

\section{3 pTEA *-mA}

\section{1 pJ *-m}

The deverbal noun suffix $\mathrm{pJ}^{{ }^{\star}-m}$ can be reconstructed as a suffix that derived nominal and adnominal forms from verbal adjectives. The evidence comes from the accent class 2.5 of disyllabic nouns with a unique low-falling pitch, which is limited to the Kansai dialects. Polivanov (1924: 126) was the first to link the origins of this accent class with the loss of a final consonant $\mathrm{pJ}^{\star}{ }^{\star}-m$. Vovin (1994: 250, 2008: 142-150); identifies the lost consonant as the nominalizer pre-pJ ${ }^{\star}-m$ in verbal adjectives often denoting colors, such as in OJ awo- B 'to be blue/ green' and derived awo 2.5 'blue/green (n.)' (< *awo- 'be blue/green' $+{ }^{\star}$ - $m$ NML). The vowel alternation in some adjectives such as OJ kura- B 'to be dark' OJ kuro ${ }_{1}$ 2.5. 'black' and OJ sira- B OJ siro ${ }_{1} 2.5$. 'white' suggests that the copula ${ }^{\star} w o$ - 'to be' may be involved in the derivation, yielding ${ }^{\star} k u r a-w o-m$ (thick-COPNML) and *sira-wo-m (thick-COP-NML) respectively.

Clausal (ad)nominalization makes use of a suffix $\mathrm{pJ}^{\star}$-om reflected as $-u$ in Old Japanese and as ${ }^{\star}$-um in the Ryukyuan languages, which may go back to a complex form pJ ${ }^{\star} w o-m$ consisting of a copula ${ }^{\star} w o$ - and the deverbal noun suffix 
${ }^{\star}$ - $m$ (Robbeets 2015: 361-365). Although the standard use of WOJ - $u$ and Ryukyuan ${ }^{\star}$-um is finite as in (11d), we find a few relic examples of nonfinite use. As a nominalizer, it is preserved following the negative suffix $\mathrm{OJ}-(a) z$-in constructions, where the negative nominalizer -(a)zu occurs before the converb $n i$ of the defective copula $n$ - or before the converb site of the verb se- 'to do' (Vovin 2009: 760-763); see (11b). Adnominal use of $-u$ surfaces in some lexicalizations, such as J izumi '(well-)spring' which derives from ${ }^{\star} i d-u m_{1}$ (emerge-ADN water) and OJ $y o_{2} s-u-k a$ (stop-ADN-place) 'a place to hold' (MYS VII: 1382; BS 18; Martin 1987: 807). There are also instances where vowel-stem verbs, such as OJ mi te- 'to fill (tr.)' in (11c), take an adnominal form on $-u$ instead of the standard $-u r u$.

(11) Reflexes of the deverbal noun suffix $\mathrm{pJ}^{\star}{ }^{\star}-m$ in Western Old Japanese

a. Lexical (ad)nominalization

siro $_{1} \quad$ kami $_{1}$

white hair

'grey hair'

(MYS 27: 3922)

b. Clausal nominalization

amata pa ne-z-u n-i tada $\mathrm{pi}_{1} \mathrm{to}_{2} \mathrm{yo}_{1} \quad \mathrm{no}_{2} \mathrm{mi}_{2}$

many TOP sleep-NEG-NML be-CONV only one night PT

'not sleeping [with her] many [nights], only one night'

(NK 66)

c. Relative clause

$\mathrm{so}_{1} \mathrm{ra} \mathrm{mi}_{1} \mathrm{t}$-u Yamato-no kuni-ni

sky fill-ADN Yamato-GEN land-LOC

'in the land of sky-filling Yamato'

(K 722; Martin 1987: 809)

d. Independent sentence

$a k i_{1}-n o_{2} \quad n o_{1}-n i \quad$ sawosika nak-i $i_{1}-t-u$.

autumn-GEN field-LOC male.deer cry-CONV-PERF-FIN

'Male deer cried in the autumn field.'

(MYS 25: 3678; Vovin 2009: 602)

The examples in (11) suggest that before $\mathrm{pJ}^{{ }^{*}}$-ra started to grammaticalize, an earlier cycle of parallel grammaticalization had already taken place in Japanese, involving the derivational nominalizer $\mathrm{pJ}^{{ }^{\star}}{ }^{*} m$. Similarly, lexical nouns were derived by adding the suffix ${ }^{\star}-m$ directly to verbal stems, whereas clausal (ad)nominalizations incorporated the copula *wo- 'to be'. These clausal (ad)nominalization ultimately developed to mark syntactically independent sentences. 


\section{$3.2 \mathrm{pK} *-\mathrm{m}$}

As in Contemporary Korean, the Middle Korean deverbal noun suffix MK $-(\cdot u / o)$ $m$ was used to derive lexical nouns and to nominalize sentences, but in Middle Korean, the morphology of these two uses was different (Lee and Ramsey 2011: 176-177). Lexical nouns were generally derived by adding the suffix directly to verb stems, while clausal nominalizations incorporated the modulator MK $\cdot \cdot w^{u}$ / $o$-, which has been derived from an original copular verb $\mathrm{pK}{ }^{\star}{ }^{*} o^{-}$. This distinction is illustrated in Example (12a), but it already showed instability in the fifteenth century and fell into disuse in the sixteenth century, yielding many exceptions to this rule such as (12b).

Except for some expressions such as K wul-um swori (cry-NML voice) 'a tearful voice', where the nominal modification can be interpreted as an unmarked genitive case, the suffix is not used as an adnominalizer but it can appear as a marker of finiteness. As illustrated in (12c), the Middle Korean finite $-(\cdot u / o) m$ is always followed by the vocative particle $a$, which is also incorporated in the subjunctive attentive MK $-(\cdot u / o) \cdot l a$, discussed in Section 2.2. In the documentary style of written contemporary Korean $\mathrm{K}-(u) m$ appears in main clauses without the vocative, often expressing an impersonal proposition as in (12d).

(12) Reflexes of the deverbal noun suffix $\mathrm{pK}^{\star}$ - $m$ in Korean

a. Lexical nominalization vs. clausal nominalization in Middle Korean tywoh-on yel-um yel-wu-m-i

be.good-ADN bear.fruit-NML bear.fruit-MOD-NML-NOM

'the bearing of good fruit'

(1459 Wel 1: 12; Lee and Ramsey 2011: 177)

b. Clausal nominalization in Middle Korean

kes-ul meki-m-i mastang thi ani ho-n-i

thing-ACC feed-NML-NOM proper do.SUSP NEG do-ADN-NML

'It is unsuitable to feed them things [such as watermelon or pear or orange]'

(1608 Twu-cip 2: 4b; Martin 1992: 887)

c. Independent sentence in Middle Korean

$\cdot n a-y$ ne to.ly-e nil.G-wo-·m-a

I-NOM you accompany-CONV say-MOD-FIN-VOC

'I will tell you.'

(1517 Pak 1: 32b; Martin 1992: 932)

d. Independent sentence in Korean

onul-un swuep-i eps-um.

today-TOP class-NOM not.exist-NML

'No class today.' 
The examples in (12) suggest that a cycle of grammatical change involving the derivational nominalizer $\mathrm{pK}{ }^{\star}-m$ took place in Korean, parallel to the development described in Section 2.2. Similarly, lexical nouns were derived by adding the suffix $\mathrm{pK}{ }^{\star}-m$ directly to verbal stems, whereas clausal (ad)nominalizations incorporated the copula $\mathrm{pK}{ }^{\star} w \boldsymbol{O}^{-}$'to be' and ultimately developed to mark syntactically independent sentences in particular discourse contexts. As such,

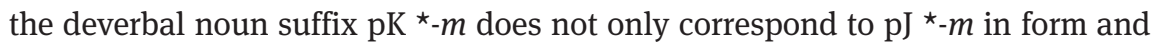
function, but the correlations also involve the incorporation of a cognate copula ${ }^{\star} w o$ - 'to be' in clausal (ad)nominalization as well as the different stages in the development to finite use and the cyclicity of the development.

\section{$3.3 \mathrm{pTg} *-\mathrm{mA}$}

The deverbal noun suffix pTg ${ }^{*}-m A$ can be reconstructed as a suffix that derived nominal and adnominal forms from verb stems, such as in Evenki girku- 'to walk' $\rightarrow$ girkuma 'pedestrian', omngo- 'forget' $\rightarrow$ omngomo 'forgetful, absent-minded', tuksa- 'run' $\rightarrow$ tuksama 'running', muru- 'to walk round, return' $\rightarrow$ murume 'round' (Poppe 1955: 262, Menges 1968: 67, Nedjalkov 1997: 305) and in Udehe sigili- 'stir' $\rightarrow$ sigilime 'thick soup', kua- 'cut, make a frame-work' $\rightarrow$ kuaima 'log', xui- 'boil' $\rightarrow$ xuili-me 'boiling', zegde- 'burn' $\rightarrow$ zegdelime 'burning' (Nikolaeva 1999: 113). It is particularly frequent in the derivation of colour nouns and adjectives, such as Evk. bagda- 'to become white, freeze' $\rightarrow$ bagdama 'white (adj. and n.)', Evk. konno- 'to be black' $\rightarrow$ konnomo 'black (adj. and n.)' and pTg *pula- 'to be red' (in Evk. hularin 'red', Even hulal- 'to become red', hulańa- 'red') $\rightarrow$ Evk. hulama 'red (adj. and n.)', which recalls the color derivations in Japanese in Section 3.1.

In Sibe, a contemporary descendant of Manchu, the corresponding suffix $-m$ is still productive as the citation form of verbs and is used for deriving infinitives as in (13a) as well as for marking independent clauses as in (13d).

As illustrated in (13c), most Tungusic languages use a converb suffix with distinct singular and plural forms, e. g., Evk. -mi /-mil, Nanai -mi /-mari /-meri, Ud. -mi /-mei, Olč -mi /-mari /-meri, Oroč -mi /-mai. This number distinction reflects contraction of an original clausal nominalizer pTg ${ }^{\star}-m A$ with the possessive-reflexive suffixes pTg *-wi singular and pTg * -wari plural, respectively (Benzing 1955: 1090; Menges 1968: 212). The presence of the possessive-reflexive marker gives the converb an inherently co-referential function, which means that it can only be used in same-subject constructions. Unlike other converb suffixes, the use of the ${ }^{\star}-m i\left(<{ }^{*}-m A\right.$-wi) converb as a nominalizer in complement clauses as in (13b) is characteristic of all Tungusic languages, an observation that also supports the proposed origin of the suffix. 
(13) Reflexes of the deverbal noun suffix pTg ${ }^{\star}-m A$ in Tungusic

a. Infinitive in Sibe

tumaqe da er sahenzi-ni da songu-m songu-me

and.then PT this daughter-POSS PT cry-INF cry-CONV

'And then this daughter cried and ...' (Jang and Payne 2012: 234)

b. Clausal nominalization in Udehe

min-du o-du te:-mi aya.

me-DAT here-DAT sit-NML good.

'It is nice for me to sit here'

(Nikolaeva 1999: 164)

c. Clausal adverbialization in Nanai

naisal giam-ba duere-meri, yari-xa-ci.

people road-ACC walk-CONV.PL sing-PERF-3SG

'People were singing as they were walking along the road.'

(Avrorin 1961: 142)

d. Independent clause in Sibe

am nane-ni gel xia-ve-mak niumku bahe-m.

big person-DEF also bite-PASS-CONV disease get-IPF.FIN

'Even adults get bitten and get disease.'

(Jang et al. [in prep.])

The examples in (13) suggest that a cycle of grammatical change involving the derivational (ad)nominalizer $\mathrm{pTg}{ }^{\star}-m A$ took place in Tungusic, parallel to the development for $\mathrm{pTg}{ }^{{ }^{*}}-r A$ described in Section 2.3. The suffix was extended to the clause level, leaving a trace in clausal adverbialization, which can be derived from original nominalization. Although in most Tungusic languages, the suffix either did not undergo insubordination or was replaced by newer items such as pTg ${ }^{*}-r A$, Sibe leaves a trace of the use of the suffix in independent clauses.

\section{$3.4 \mathrm{pMo} *-\mathrm{mA}$}

The deverbal noun suffix pMo ${ }^{\star}-m A$ alternates with ${ }^{*}-m$ and can be reconstructed as a suffix that derived nominal and adnominal forms from verb stems, such as in MMo. daqa- 'to follow (tr.)' $\rightarrow$ daqama 'menses', WMo. jagura- 'to jam, be arrested in motion' $\rightarrow$ jagurma 'interrupted, incomplete; that which has not reached its end; on the way (n./adj./adv.)', WMo ulayi- 'to get red-hot, become red (intr.)' $\rightarrow$ ulayima 'red, red-hot', MMo. quri- 'to come together (intr.)' $\rightarrow$ qurim 'feast', WMo. toqo- 'to saddle (tr.)' $\rightarrow$ toqom 'saddle cloth', WMo. to yuri- 'to go about, circle, surround (tr.)' $\rightarrow$ WMo. to ${ }^{\prime}$ urim 'approximate, around; environment (n./adj)' (Poppe 1954: 47-48, 
1955: 261-262; Street 1957: 58). There are doublets, such as degerem degerme 'robbery, robber' from pMo *degere- 'to lift (tr.)' in degerede- 'to be lifted' and to yum to yuma 'sensibleness; good behavior' from WMo. toVu- 'to esteem, value' that indicate that the (ad)nominalizers ${ }^{\star}$ - $m a$ and ${ }^{\star}$ - $m$ share a common origin.

Janhunen (2010: 166-167) notes that the marker of the preconditional converb $-m A A / n$ in the Central Mongolic languages, e. g., sour-maa/n (study-CONV) 'only if you study', can be derived from the deverbal noun suffix $-m$ and the reflexive possessive marker $-A A / n$. This identification is confirmed by the fact that the final / $n$ follows the pattern of the possessive-reflexive marker, being present in some dialects (as in Chakhar) and absent in others (as in Khalkha). Similar to the Tungusic converb in Section 3.3, the possessive-reflexive marker gives the converb an inherently co-referential function. As such, clausal adverbialization can be derived from clausal nominalization.

In Middle Mongolian texts of the thirteenth and fourteenth century, - $m$ is the common ending for the imperfective present indicative (Poppe 1955: 261; Weiers 1966: 143-150); see (14b). This suffix is used less in Written Mongolian, where it has been replaced by $-m U i$ or $-m U$.

(14) Reflexes of the deverbal noun suffix pMo ${ }^{*}-m A \sim{ }^{*}-m$ in Mongolic

a. Lexical (ad)nominalization

jayilu-ma usu

rinse-NML water

'brook'

b. Independent sentence

MMo. udurit-basu ber ulu busire-m.

guide-COND PT NEG believe-IPF.FIN

'Even if you guide them, they don't believe'

(HY; Weiers 1966: 144)

The examples in (14) suggest that a cycle of grammatical change involving the derivational (ad)nominalizer pMo ${ }^{\star}-m A \sim^{*}-m$ has taken place in Mongolic, paralleling the development for $\mathrm{pMo}{ }^{*}-r$ described in Section 2.4. The suffix was extended to the clause level, the original clausal nominalization leaving a trace in converbial sentences in the Central Mongolic languages. Ultimately, the suffix developed into an imperfective present marker in independent clauses.

\section{$3.5 \mathrm{pTk} *-\mathrm{mA}$}

The deverbal noun suffix pTk ${ }^{\star}-m A$ alternates with ${ }^{*}-m$ and can be reconstructed as a suffix that derived nominal and adnominal forms from verb 
stems, such as in OTk. tut- 'to hold, grasp, seize (tr.)' $\rightarrow$ tutma 'chest, coffer', OTk. yar- 'to split (open) (tr.)' $\rightarrow$ yarma 'crack', OTk. erksin- 'to have power or authority over (tr.)' $\rightarrow$ erksinme 'dominant', OTk. tut- 'to hold, grasp, seize (tr.)' $\rightarrow$ tutum 'handful', OTk. yar- 'to split (open) (tr.)' $\rightarrow$ yarïm 'half', OTk. yil- 'to catch on to something, to hang, to fasten (tr.)' $\rightarrow$ yilim yï 'creeper plant', etc. (Erdal 1991: 316-320, 1991: 290-300). Since OTk. - $m A$ and -(X)m have similar functions and produce near doublets such as OTk. örüm 'something knitted' örma 'plaited', they probably go back to a single origin. There are some rare cases of relative clauses such as (15b) below, in which the noun but 'leg' is governed by the $-m A$ form. There are no indications that this suffix has developed finite function.

(15) Reflexes of the deverbal noun suffix pTk ${ }^{\star}-m A \sim^{*}-m$ in Old Turkic

a. Lexical (ad)nominalization

ör-me sač

plait-NML hair

'plaited hair'

b. Relative clause

but kötür-me tïnlig

leg lift.up-ADN living.being

'a living being lifted up by [its] legs'

(Erdal 1991: 319)

\section{Direct insubordination as a driving force in Transeurasian grammar}

\subsection{Comparative analysis}

Comparison of the above developments leads to the reconstruction of two distinct deverbal noun suffixes ${ }^{{ }^{*}}-r A$ and ${ }^{{ }^{*}}-m A$ in the presumed ancestral Transeurasian language, illustrated in Table 1. Derived nouns expressing properties were juxtaposed to other nominals, thus functioning as nominally encoded adjectives. The deverbal noun suffixes were then extended to the clause level to mark clausal nominalization in complement clauses. Relative clauses developed from cases in which a nominalized complement clause stood in apposition to a head noun. This process may already have been initiated in proto-Transeurasian, but the proto-Japanese-Korean branch 
Table 1: Comparison of the development of finiteness on common deverbal noun suffixes in the Transeurasian languages.

\begin{tabular}{|c|c|c|c|c|c|c|}
\hline & pTEA & pJ & pK & pTg & pMo & pTk \\
\hline 1 & $\begin{array}{l}{ }^{*} \text {-mA } \\
\text { lexical NML }\end{array}$ & $\begin{array}{l}\text { *-m } \\
\text { lexical NML } \\
\text { *-wo-m } \\
\text { clausal NML } \\
\text { clausal ADN } \\
\text { independent }\end{array}$ & $\begin{array}{l}\text { *-m } \\
\text { lexical NML } \\
\text { *-wo-m } \\
\text { clausal NML } \\
- \\
\text { independent }\end{array}$ & $\begin{array}{l}\text { *-mA } \\
\text { lexical NML } \\
\text { clausal NML } \\
\text { clausal CONV } \\
\text { independent }\end{array}$ & $\begin{array}{l}\text { *-mA } \\
\text { lexical NML } \\
\text { clausal CONV } \\
\text { independent }\end{array}$ & $\begin{array}{l}\text { *-mA } \\
\text { lexical NML } \\
- \\
\text { clausal ADN } \\
-\end{array}$ \\
\hline 2 & $\begin{array}{l}{ }^{*} \text {-rA } \\
\text { lexical NML }\end{array}$ & $\begin{array}{l}\text { *-ra } \\
\text { lexical NML } \\
\text { *-wo-ra } \\
\text { clausal NML } \\
\text { clausal ADN } \\
\text { independent }\end{array}$ & $\begin{array}{l}\text { *-I } \\
\text { lexical NML } \\
\text { *-wo-l }_{\text {clausal NML }} \\
\text { clausal ADN } \\
\text { independent }\end{array}$ & $\begin{array}{l}\text { *-rA } \\
\text { lexical NML } \\
\text { clausal NML } \\
\text { clausal ADN } \\
\text { independent }\end{array}$ & $\begin{array}{l}{ }^{{ }_{-}-\mathrm{r}} \\
\text { lexical NML } \\
\text { clausal NML } \\
- \\
\text { (independent) }\end{array}$ & $\begin{array}{l}\text { *-(COP)-rV } \\
\text { lexical NML } \\
- \\
\text { clausal ADN } \\
\text { independent }\end{array}$ \\
\hline
\end{tabular}

underwent a common innovation in the sense that it incorporated a common copula *wo- 'to be' for the derivation of clausal (ad)nominalization. Relative clauses then developed one step further to mark syntactically independent sentences. Because the Japanese and Korean independent constructions still clearly mark supplementary information in discourse, their development seems to be relatively late in the course of individual linguistic history.

The common Altaic deverbal noun suffix * ${ }^{\star}$ A may have been extended to the clause level and developed to mark independent sentences, before the separation of the Turkic branch. The common Tungusic-Mongolic suffix ${ }^{\star}-m A$, however, separated from the Turkic nominalizer at the stage when complementation was accomplished, but the use as a marker of adverbial and relative clauses had not developed yet. The suffix ${ }^{\star}-m A$ specialized for converbial use in the common ancestor of Tungusic and Mongolic and after the split of both families, the native possessive-reflexive markers were added to express co-referential function in same-subject constructions. The Tungusic-Mongolic nominalizer ${ }^{\star}-m A$ further developed to mark syntactically independent sentences. Initially, these constructions may have added supplementary information, but gradually they generalized into the default indicative ending. The Turkic reflexes of pTk ${ }^{\star}-m A$ came to be used in relative clauses, but not in independent sentences. In this way, the development of finiteness on common deverbal noun suffixes in the Transeurasian languages seems to support the branching of the Transeurasian family proposed in Figure 1 on the basis of other shared innovations (see Robbeets 2005, 2015). 


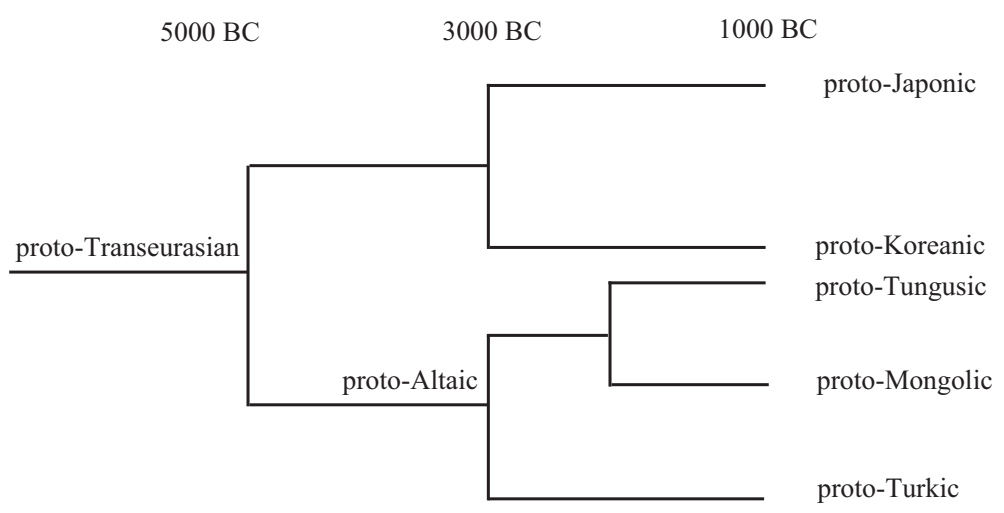

Figure 1: Assumed branching of the Transeurasian family.

\subsection{Direct insubordination in Transeurasian}

The comparative evidence above thus indicates that the nominalization construction began as a derivational process at the lexical level, was then extended to dependent clauses at the syntactic level, and was eventually - through a pragmatic role in discourse - extended still further to independent clauses. This is a development to which Evans' (2007: 367) term "insubordination" can be applied because formally dependent clauses become conventionalized as independent clauses, which draw their morphological marking only from the former dependent clause.

On the basis of classical definitions such as Kurylowicz (1965: 52) or Heine and Reh (1984: 15) that describe grammaticalization in terms of an increase of grammatical status and a loss of semantic content, phonetic substance, categorial properties, and syntactic freedom, the processes of insubordination explored above can be characterized as grammaticalization. First, the gradual transition from derivation to inflection reflects an increase of grammatical status, whereby the cline is from deverbal noun affixes over participial affixes to finite affixes. Second, semantic content is gradually lost as one moves on the insubordination cline since nonfinite suffixes may change the meaning of the base, as opposed to finite markers. Third, some relativizers and finite affixes above are phonologically reduced vis-à-vis their deverbal nominal sources. Fourth, insubordination involves loss of categorial properties because it can be viewed as a gradual process of denominalization, in line with Malchukov's (2004: 88-93) view. Finally, syntactic 
freedom is lost because the use of a deverbal noun suffix is optional in a sentence, while the use of a finite marker is obligatory.

Since the examples given above do not involve the ellipsis of a matrix verb, they can be subsumed under "direct insubordination": the nominalized forms are directly reanalyzed as finite forms rather than being part of an original copula construction that became verbalized and then lost its copula. This can be deduced from the observation that the examples above show virtually no trace of an eroding copula such as the final particle in (3b). And even if these nominalized forms appear as complements of finite copular verbs 'to be' or 'to become' in rare cases, historical and comparative evidence suggests that these copula represent later additions under influence of contact languages and/or to allow for maximum inflectional marking on the insubordinated nominalized form.

The Manchu finite imperfective -mbi illustrated in (16a), for instance, corresponds to the Sibe - $m$ marking independent clauses without copula intervention in (13c) (Gorelova 2002: 232, 286-288, 441-443). This form can be derived from a reflex of the Tungusic nominalizer ${ }^{\star}-m A$ and the Manchu predicative copula Ma. $b i$, which is an obligatory component in nominal predication.

(19) Finite imperfective - $m b i$ in Manchu

a. indahu:n dobori tuwahiya-mbi, coko erde dog night guard-FIN chicken early.in.the.morning hu:la-mbi. sing-FIN

'A dog keeps guard at night, a rooster crows early in the morning.' (Orlov 1873: 193; Gorelova 2002: 287)

b. bi kwmuni ere-be niyalma-de ere-mbi-he

I constantly this-ACC people-DAT hope-FIN-PST

'I constantly inspired people with this hope'

(Orlov 1873: 194; Gorelova 2002: 445)

The Manchu imperfective in -mbi has a parallel in the finite past in -hAbi, which alternates with the simplex finite past in $-h A$ and is derivable from the perfective adnominalizer Ma. $-h A\left(<\mathrm{pTg}{ }^{\star}-g A\right)$ and the predicative copula bi (Gorelova 2002: 123, 232, 290-291, 444, 470, 533). These forms are illustrated in (20a) to (20c). It can be argued that the Manchu alternant in - $h A$ reflects the original construction, which developed through direct insubordination from the perfective adnominalizer because in Northern Tungusic languages such as Even and Southern Tungusic languages such as Nanai and Udehe the corresponding finite perfect suffix is not accompanied by a 
copula; see (20c). This is supported by the observation that there is no alternative past form in ${ }^{\star \star}-k A b i$, in which the copula would have followed the original allomorph of Ma. $-h A$. Parallelly, the Sibe $-m$ marking independent clauses without copula intervention probably reflects the original construction. It is not unlikely that the copula constructions in Manchu, a highly siniticized language, developed under Chinese influence. The addition of the copula enables the speaker to mark the insubordinated form with the maximum of inflectional categories, such as the addition of tense marking in (19b).

(20) Reflexes of the perfective adnominalizer ${ }^{\star}-g A$ in Tungusic

a. perfective adnominalizer in Manchu

ere abala-me gene-he gucu-sa

this hunt-CONV go-PF.ADN companion-PL

'companions, who have gone hunting'

(SK 64, Gorelova 2002: 257)

b. finite past in Manchu

deo gene-he

younger.brother go-PST.FIN

'The younger brother went away'

c. finite past in Manchu

nimanggi-i elden-de bithe hu:la-habi

snow-GEN light-DAT book read-PST.FIN

'[He] read the book in the light [reflected by] the snow.'

d. finite perfect in Udehe

Bi emegi-ge-i

I come-PERF-1SG

'I have come back'

(Nikolaeva 1999: 148)

There are other instances across the Transeurasian languages, such as in Mongolian and Japanese, where historical evidence suggests that copula are added to nominalized forms, only after these forms have directly developed into markers of finiteness. Although in Khalkha and other Central Mongolic languages the temporal-aspectual nominalizers - $(e) x$ future, -deg habitual and -g.AA continuative occur either obligatorily or optionally with a copula yum in independent clauses, the use of a copula following the temporal-aspectual nominalizers seems to be rather rare in Middle Mongolian. Even though the future nominalizer - $(e) x$ in (21c) obligatorily takes a copula in finite position, the Middle Mongolian imperfective nominalizer $-K U$ from which it descends appeared more often than not 
without a copula in independent clauses; see (21b). Having made a rough count, Rybatzki (p.c.) finds that in Middle Mongolian, nominalizers indicating finite forms occur more frequently without intervention of a copula. He therefore assumes that the use of a copula is a secondary development in Mongolic, which might be influenced by Turkic languages where a similar structure of adnominalizer plus copula (e. g., OTk. -mIš ärti) is rather common and earlier than in Mongolic texts.

(21) Development of the imperfective nominalizer MMo. -KU

a. Clausal nominalization in Middle Mongolian

naran urqu-qu-yin urida

sun rise-NML-GEN before

'before the sun rose'

(SH 90; Street 1957: 24)

b. Independent sentence in Middle Mongolian

qa'ulu'a ino ulu olu-qu ci

way his NEG find-FIN.FUT 2SG

'you will not find his way'

(Weiers 1966: 181)

c. Finite copula construction in Khalka

bid margaaš ted-en-tej uulza-x yum

we tomorrow 3-PL-COM meet-FUT be

'We shall meet them tomorrow'

(Bisang 2016: 24)

Note that the assumption of secondary addition of copula in Mongolic solves Mithun's (2008: 102) puzzle that - contrary to other nonfinite forms in Khalka, which have directly extended to markers of finiteness - the use of the temporalaspectual nominalizers as finite forms "does not appear to be the result of direct extension, however. They appear in compound tense formations, as complements of a finite verb 'be' or 'become'”. The observation that these copula constructions may be secondary further contradicts Bisang's (2016: 24) viewpoint that the use of the copula yum in Example (21c) can be seen as an indication of original clefting, whereby subsequent copula loss would lead to the development of finite future function on the nominalizer. It does not alter Bisang's basic argumentation, however, that the development of finiteness in these examples is primarily driven by information structure.

It has also been argued that the use of nominalizers as finite forms in Japanese derives from finite copula constructions, in which the copula has been lost (Yap et al. 2004; Yap and Matthews 2008: 6-9; Horie 2008: 176-177; 
Bisang 2016: 28). Wrona (2011), however, provides historical evidence from Japanese, showing that some finite nominalizations such as the ones marked by -sa have never been embedded by a copula throughout the history of the Japanese language, whereas for others such as nominalizations with no and koto the socalled "stand-alone" type of nominalization is attested before the copula type. There are, for instance, no examples of a finite copula following $\mathrm{kO}_{2} \mathrm{to}_{2}$ in Old Japanese; only examples of the type illustrated in (21b) are found. Copula constructions as in the contemporary Japanese example in (21c) emerged later in Japanese history, perhaps under Chinese influence.

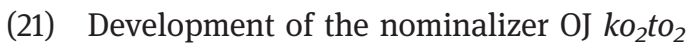

a. Clausal nominalization in Old Japanese ip-umasizi-ki $\quad \mathrm{ko}_{2} \mathrm{to}_{2} \mathrm{mo}_{2}$ ip-i $\mathrm{i}_{1}-\mathrm{n}-\mathrm{u}$ say-NEG.POT-ADN thing PT say-CONV-PERF-FIN '[He] also said things that [he] should not have said.' (SM 27)

b. Independent sentence in Old Japanese karakuni-wo ika-ni ip-u $\mathrm{kO}_{2} \mathrm{to}_{2} \mathrm{SO}_{2}$ land.of.Kara-VOC why-DAT say-ADN NML PT 'Oh, the land of Kara! Why is it called so?'

c. Finite copula construction in Japanese

$\begin{array}{llll}\text { Nani-yori } & \text { daiji-na } & \text { koto-wa } & \text { hanasiai-de } \\ \text { what-ABL } & \text { important-ADN } & \text { thing-TOP } & \text { talk-INST } \\ \text { kaiketsu } & \text { suru } & \text { koto } & \text { da. } \\ \text { solution } & \text { make } & \text { NML } & \text { be }\end{array}$

'The most important thing is to find a solution through talks' (Kaiser et al. 2001: 223)

In sum, direct insubordination is a recurrent development across the Transeurasian languages. A serious number of insubordinated nominalizations in these languages have never been embedded by a copula and even if they have been, historical and comparative evidence frequently suggests that the copula represents a secondary addition. It is not unlikely that copula were added under influence of contact languages and/or to allow for maximum inflectional marking on the insubordinated nominalized form.

\subsection{Finitization in adjacent areas and families}

In other parts of Asia clausal nominalization in constructions with a copula is, nevertheless, a major source for developing new finite constructions. Many 
Sinitic languages use focus constructions consisting of a nominalizer plus a copula verb and dropping the copula then paves the way for finite stance constructions. The Mandarin shi ... de focus constructions, for instance, consist of a copula shi and a nominalizer de, whereas the finite stance construction appears without the copula (Yap and Matthews 2008: 20). Similar processes are found in the Siberian area, for instance in Yukaghir (Malchukov 2013: 192-195). In Kolyma Yukaghir, the suffix $-l$ is used to derive action nouns, anterior participles and indicative finite forms in subject focus constructions, as illustrated in (22). The intransitive subject ' $\mathrm{I}$ ' in (22b) takes a focus marker -ek, which is also used to mark nominal predicates, thus pointing to an origin as a copulalike form. As such, the example in (22b) can be derived from a cleft-like construction "It is me sitting".

(22) Development of the Kolyma Yukaghir nominalizer -1

a. odupe modo-l jalhil-pe-gi

Yukaghir live-PF.PCP lake-PL-POSS

'The lake where the Yukaghirs lived'

(Malchukov 2013: 194)

b. Met-ek modo-l

I-FOC sit-FIN

'I sit'

(Malchukov 2013: 194)

As demonstrated by several scholars (e. g., Matisoff 1972; Noonan 1997; Bickel 1999; DeLancey 2011), nominalizer plus copula constructions are also the major source of finitization in the Tibeto-Burman family. Finite verb forms in Modern Tibetan such as -pa yin, -pa red, for instance, transparently reflect a copula construction, consisting of a nominalizer - $p a$ followed by an equational copula. As such, constructions become more opaque, the copula may develop into a semantically empty final particle as in Example (3b).

As opposed to the situation in the Transeurasian languages, final particles and focus markers leaving a trace of an eroding copula prevail in languages that develop finiteness from nominalization in construction with a copula. As such, the inherent mechanism for developing finiteness in the Transeurasian family is demonstrably distinct from that used in the Sinitic, Yukaghir or Tibeto-Burman languages.

This does not mean, however, that the frequency and concentration of the process of "direct insubordination" in the Transeurasian languages by itself should be taken as evidence of common ancestorship. Mithun (2008: 102) finds that processes of direct insubordination are undoubtedly more common 
crosslinguistically than has hitherto been recognized, partly because traditional studies have focused on isolated sentences rather than on longer stretches of discourse. Given the frequency of the process crosslinguistically, sharing "direct insubordination" may be the result of universal principles in linguistic structuring rather than a shared linguistic history. Moreover, as far as the concentration of the process is concerned, direct insubordination seems to be particularly concentrated in the wider Transeurasian contact zone, appearing among others in Uralic languages, Eskimo and Nivkh.

In Nivkh, for instance, the deverbal action noun and infinitive suffix - $d$ ' has developed over participial use into a finite form - $d$ ', as illustrated in Example (23), which illustrates both the nonfinite and finite use of the suffix. Since Nivkh has had close contact with Tungusic languages situated to the east such as Olcha, Oroch, Orok, Nanai, Udehe, Negidal and Evenki, it is not unlikely that the development was induced by language contact. ${ }^{3}$ Note that Anderson (2006: 25) finds that "the features of the Siberian linguistic macro-area cluster around those of the Northern Tungusic languages" and refers to the Tungusic languages as "vectors of diffusion". However, rather than being a case of "direct insubordination”, Gruzdeva (2016: 196) attributes the development to the lexicalization of a modally marked form of the copular verb ha- 'do so'. When the modally marked copula was lexicalized into a modal particle, - $d$ ' was reanalyzed as a finite form.

(23) Nivkh

If hum-d' hyjm-d'

he live-NML know-FIN

'He knows the living one.'

'He knows (his) life.'

(Malchukov 2004: 121, 2013: 200)

\subsection{Genealogical motivation}

Even if direct insubordination can diffuse from one language to another as it probably did in the Siberian area, there are indications that the direct insubordination shared across the Transeurasian languages is genealogically motivated. The main indication is that the process of direct insubordination is shared on

3 However, Kortlandt (2004: 4) identified the Nivkh suffix - $d$ ' with the Indo-Uralic participial suffix ${ }^{\star}-n t$, considering it as a piece of evidence for a common origin. As such, the direct insubordination may also represent an ancestral feature. 
formally corresponding suffixes, such as the common forms ${ }^{{ }^{*}}-r A$ and ${ }^{*}-m A$ above. For the assumption that globally shared grammaticalization - or any input and output of grammatical change shared on formally corresponding morphemes - is a strong indication of genealogical relatedness, I refer to Robbeets (2013). ${ }^{4}$ Within a borrowing scenario, the global correspondences of ${ }^{\star}$ - $r A$ should be explained as follows: first, the recipient language, say Mongolic, borrowed nominalized verbs of the model language, say Turkic. Second, the contact was intensive in such a way that the underlying verb roots were borrowed as well. Third, following a massive borrowing of verb roots, Mongolic speakers saw the relation between the borrowed verb base and the borrowed nominalization and started to apply ${ }^{\star}$-rA productively in their own language. At this stage, Mongolic had globally copied the Turkic suffix, but the borrowing of the outcome of grammatical change was yet to come. Later in the history of Turkic, the nominalizer developed into a marker of finiteness. Fifth, Mongolic speakers, drawing an equivalence between their earlier borrowed nominalizer ${ }^{\star}$ - $r A$ and the Turkic adnominalizer, fill the gap by borrowing the finite function. This process has to be repeated pairwise four times between Mongolic and Tungusic, Tungusic and Koreanic and so on, until it reaches the Japonic languages. Needless to say, such a complicated borrowing scenario, where one has to invoke chance in case after case, is highly unlikely.

Moreover, direct insubordination is not restricted to a single set of formally corresponding suffixes like those yielding the reconstruction of pTEA ${ }^{\star}-r A$. In this article, I have also discussed the development for the nominalizer ${ }^{\star}-m A$ and in Robbeets (2015), I trace the process on at least five formally corresponding suffixes. As such, the recurrence of indirect insubordination on formally related suffixes is also pointing towards common ancestorship. It is known that languages tend to renew their formal encodings in cyclic processes of grammatical change while trying to maintain their inherited grammatical categories. Therefore, newly inserted grammatical items are expected to develop along shared conceptual pathways to restore old categories (Heath 1998; Aikhenvald 2013). Consequently, genealogically motivated grammatical change is expected to recur in different forms at various points in time, while contact-induced grammatical change is expected to be restricted to a single formal encoding (or to a very limited number of encodings) during the period of contact. Therefore, I take instances of shared grammatical change whereby the specific pathway recurs in more sets of formally related morphemes as an indication of common ancestorship.

4 Note that the term "globally shared grammaticalization" is inspired by Johanson's (2002) code-copying terminology. 


\section{Conclusion}

Screening the four major mechanisms by which nonfinite verb forms can acquire morphological and syntactic properties of finiteness crosslinguistically, I have characterized "insubordination" as the development whereby nonfinite verb forms become conventionalized as finite verb forms, which draw their morphological marking only from the former subordinate construction. I have proposed the term "direct insubordination" for the subtype whereby nonfinite forms are directly reanalyzed as finite forms without the omission of a specific matrix predicate.

A comparative analysis of two sets of morphemes shared across the Transeurasian languages reveals that these markers do not only share a common form (i. e., ${ }^{\star}-r A$ and ${ }^{\star}-m A$ ) and a common function (i. e., deverbal noun suffix), but that they also share a detailed developmental pathway from nonfinite to finite markers. The comparative evidence indicates that the nominalization construction began as a derivational process at the lexical level, was then extended to dependent clauses at the syntactic level, and eventually - through a pragmatic role in discourse - extended still further to independent clauses.

There is no substantial evidence in the form of, for instance, final particles or focus markers, that this process involved an original copula construction that became verbalized and then lost its copula. Moreover, even if a nominalized form appears to have been embedded by a finite copula in some rare cases, historical and comparative evidence suggests that these copulae represent later additions, perhaps under the influence of contact languages or to allow for maximum inflectional marking on the insubordinated nominalized form. Therefore, the process at work in the etymologies under discussion can be subsumed under "direct insubordination", distinguishing it from other mechanisms of finitization in different parts of Asia, such as the frequent verbalization of nonfinite verb forms plus finite copula, present in some Paleo-Siberian languages and recurrent in Sinitic and Tibeto-Burman.

It can be argued that the direct insubordination shared across Transeurasian languages is genealogically motivated, because the input (i. e., deverbal noun suffix), intermediate stages (i. e., clausal (ad)nominalizer), and output (i. e., finite marker) of grammatical change are shared on formally corresponding morphemes and because of its cyclic recurrence on corresponding morphemes. Reconstructing the pathway of "indirect insubordination" as an inherited mechanism, does not necessarily imply that the finitization of the suffixes was already completed in proto-Transeurasian and inherited as finite/nonfinite polysemy in the daughter languages. Rather, the comparative evidence suggests that the developments took 
place on cognate suffixes independently and at different times after separation from proto-Transeurasian, but nevertheless triggered by the relationship between these languages. This phenomenon, also known as "parallelism in drift" has been observed elsewhere (Sapir 1921: 171-172; Meillet 1921: 36-43; Malkiel 1981; Keller 1994; LaPolla 1994; Joseph 2006, 2013; Aikhenvald 2013). In this way, direct insubordination can be understood as an inherited force, decisive in shaping and reshaping the grammar of the Transeurasian languages.

Acknowledgements: The research leading to these results has received funding from the European Research Council under the Horizon 2020 Program/ERC Grant Agreement n. 646612 granted to Martine Robbeets.

\section{References}

Aikhenvald, Alexandra. 2013. Areal diffusion and parallelism in drift: Shared grammaticalization patterns. In Martine Robbeets \& Hubert Cuyckens (eds.), Shared grammaticalization with special focus on the Transeurasian languages (Studies in Language Companion Series 132), 23-42. Amsterdam \& Philadelphia: John Benjamins.

Anderson, Jeffrey. 2006. Towards a typology of the Siberian linguistic area. In Yaron Matras, April McMahon \& Nigel Vincent (eds.), Linguistic areas: Convergence in historical and typological perspective, 266-300. Basingstoke: Palgrave Macmillan.

Antonov, Anton. 2007. Le rôle des suffixes nominaux en / $+r V /$ dans l'expression du lieu et de la direction en japonais et l'hypothèse de leur origine "altaïque". Paris: Institut National des Langues et Civilisations Orientales dissertation.

Avrorin, Valentin Aleksandrovič. 1961. Grammatika Nanajskogo jazyka. Tom 2. Morfologija glagol'nych i narečnych častej reči, meždometij, služevnych slov i castǐ̌č [Grammar of Nanai. Vol. 2. Morphology of verbs and adverbial parts of speech and interjections] Moscow: Nauk.

Benzing, Johannes. 1955. Die tungusischen Sprachen. Versuch einer vergleichenden Grammatik. Abhandlungen der geistes- und sozialwissenschaftlichen Klasse 11. 949-1099.

Bickel, Balthasar. 1999. Nominalization and focus constructions in some Kiranti languages. In Yogendra P. Yadava \& Warren W. Glover (eds.), Topics in Nepalese linguistics, 271-296. Kathmandu: Royal Nepal Academy.

Bisang, Walter. 2001. Finite vs. non finite languages. In Martin Haspelmath, Ekkehard König, Wulf Oesterreicher \& Wolfgang Raible (eds.), Language typology and language universals (Handbücher zur Sprach- und Kommunikationswissenschaft), vol. 2, 1400-1413. Berlin \& New York: Mouton de Gruyter.

Bisang, Walter. 2016. Finiteness, nominalization and information structure: Convergence and divergence. In Claudine Chamoreau \& Zarina Estrada-Fernández (eds.), Finiteness and nominalization (Typological Studies in Language 113), 13-42. Amsterdam \& Philadelphia: John Benjamins.

Clauson, Gerard. 1972. An etymological dictionary of pre-thirteenth-century Turkish. Oxford: Clarendon Press. 
DeLancey, Scott. 2011. Finite structures from clausal nominalization in Tibeto-Burman. In Foong Ha Yap, Karen Grunow-Harsta \& Janick Wrona (eds.), Nominalization in Asian languages (Typological Studies in Language 96), 343-359. Amsterdam \& Philadelphia: John Benjamins. Dixon, R. M. W. 1972. The Dyirbal language of North Queensland. Cambridge: Cambridge University Press.

Erdal, Marcel. 1991. Old Turkic word formation: A functional approach to the lexicon (Turcologica 7). Wiesbaden: Harrassowitz.

Erdal, Marcel. 2004. A grammar of Old Turkic. Leiden: Brill.

Evans, Nicholas. 2007. Insubordination and its uses. In Irina Nikolaeva (ed.), Finiteness: Theoretical and empirical foundations, 366-431. Oxford: Oxford University Press.

Givón, Talmy. 2001. Syntax: An introduction, vol. 2. Amsterdam \& Philadelphia: John Benjamins. Gorelova, Liliya M. 2002. Manchu grammar. Leiden: Brill.

Gruzdeva, Ekaterina. 2016. Epistemic modality and related categories in Nivkh. Studia Orientalia 117. 171-198.

Heath, Jeffrey 1998. Hermit crabs: Formal renewal of morphology by phonologically mediated affix substitution. Language 74. 728-759.

Heine, Bernd \& Reh, Mechtild. 1984. Grammaticalization and Reanalysis in African Languages. Hamburg: Helmut Buske.

Horie, Kaoru. 2008. The grammaticalization of nominalizers in Japanese and Korean. In Mará José López-Couso \& Elena Seoane (eds.), Rethinking grammaticalization: New perspectives, 169-187. Amsterdam \& Philadelphia: John Benjamins.

Jang, Taeho, Kyungsook Lim Jang \& Thomas E. Payne. in preparation. A grammar of modern spoken Xibe.

Jang, Taeho \& Thomas E. Payne. 2012. Dependency and clause combining in Xibe. In Andrej Malchukov \& Lindsay Whaley (eds.), Recent advances in Tungusic Linguistics (Turcologica 89), 229-254. Wiesbaden: Harrassowitz.

Janhunen, Juha Antero. 2010. Mongolian (London Oriental and African Language Library 19). Amsterdam \& Philadelphia: John Benjamins.

Johanson, Lars. 2002. Structural factors in Turkic language contacts. Richmond: Curzon.

Joseph, Brian D. 2006. On projecting variation back into a proto-language, with particular attention to Germanic evidence. In Thomas Cravens (ed.), Variation and reconstruction, 103-118. Amsterdam \& Philadelphia: John Benjamins.

Joseph, Brian D. 2013. Demystifying drift: A variationist account. In Martine Robbeets \& Hubert Cuyckens (eds.), Shared grammaticalization with special focus on the Transeurasian languages (Studies in Language Companion Series 132), 43-65. Amsterdam \& Philadelphia: John Benjamins.

Kaiser, Stefan, Yasuko Ichikawa, Noriko Kobayashi \& Hirofumi Yamamoto. 2001. Japanese. A comprehensive grammar. London: Routledge.

Kane, Daniel. 2009. The Kitan language and script. Leiden: Brill.

Keller, Rudi. 1994. On language change: The invisible hand in language. London: Routledge.

Kortlandt, Frederik 2004. Nivkh as a Uralo-Siberian language. In Adam Hyllested, Anders Richardt Jørgensen, Jenny Helena Larsson \& Thomas Olander (eds.), Per aspera ad asteriscos: Studia indogermanica in honorem Jens Elmegård Rasmussen sexagenarii Idibus Martiis anno MMIV, 285-289. Innsbruck: Innsbrucker Beiträge zur Sprachwissenschaft.

Kurylowicz, Jerzy. 1965. Zur Vorgeschichte des germanischen Verbalsystems. Beiträge zur Sprachwissenschaft, Volkskunde und Literaturforschung: Wolfgang Steinitz zum 60. Geburtstag, 242-247. Berlin: Akademie Verlag. 
LaPolla, Randy J. 1994. Parallel grammaticalizations in Tibeto-Birman languages: Evidence of Sapir's 'drift'. Linguistics of the Tibeto-Burman Area 17(1). 61-80.

Lee, Ki-Mun \& Robert Ramsey. 2011. A history of the Korean language. Cambridge: Cambridge University Press.

Malchukov, Andrej. 2004. Nominalization/verbalization: Constraining a typology of transcategorial operations. Munich: Lincom.

Malchukov, Andrej 2006. Constraining nominalization: Function/form competition. Linguistics 44(5). 973-1009.

Malchukov, Andrej 2013. Verbalization and insubordination in Siberian languages. In Martine Robbeets \& Hubert Cuyckens (eds.), Shared grammaticalization with special focus on the Transeurasian languages (Studies in Language Companion Series 132), 177-208.

Amsterdam \& Philadelphia: John Benjamins.

Malkiel, Yakov. 1981. Drift, slope, and slant: Background of, and variations upon, a Sapirian theme. Language 57(3). 535-557.

Martin, Samuel Elmo. 1987. The Japanese language through time. New Haven, CT: Yale University Press.

Martin, Samuel Elmo. 1992. A reference grammar of Korean. Tokyo: Tuttle.

Martin, Samuel Elmo. 1996. Consonant lenition in Korean and the Macro-Altaic question. Honolulu: University of Hawaii Press.

Martin, Samuel Elmo. 2002. Coming and going: Deictic verbs in Korean and Japanese. In SangOak Lee \& Gregory K. Iverson (eds.), Pathways into Korean language and culture: Essays in honor of Young-Key Kim-Renaud, 373-381. Seoul: Pagijong Press.

Martin, Samuel Elmo. 2006. What do Japanese and Korean have in common? The history of certain grammaticalizations. Korean Linguistics 13. 219-234.

Matisoff, James. 1972. Lahu nominalization, relativization and genitivization. In John Kimball (ed.), Syntax and semantics, vol. 1, 237-257. New York: Seminar Press.

Meillet, Antoine. 1921. Linguistique historique et linguistique générale. Paris: Honoré Champion.

Menges, Karl Heinrich. 1968. Die Tungusischen Sprachen (Handbuch der Orientalistik 1: Der Nahe und der Mittlere Osten 5: Altaistik 3: Tungusologie.) Leiden: Brill.

Mithun, Marianne. 2008. The extension of dependency beyond the sentence. Language 84(1). 69-119.

Mithun, Marianne. 2016. Shifting finiteness in nominalization: From definitization to refinitization: Finiteness and nominalization. In Claudine Chamoreau \& Zarina Estrada-Fernández (eds.), Finiteness and nominalization (Typological Studies in Language 113), 297-322. Amsterdam \& Philadelphia: John Benjamins.

Nedjalkov, Igor 1995. Converbs in Evenki. In Martin Haspelmath \& Ekkehard König (eds.) Converbs in cross-linguistic perspective: Structure and meaning of adverbial verb forms adverbial participles, gerunds (Empirical Approaches to Language Typology 13), 97-136. Berlin \& New York: Mouton de Gruyter.

Nedjalkov, Igor V. 1997. Evenki: Descriptive grammar. London: Routledge.

Nikolaeva, Irina 1999. A Grammar of Udehe. Leiden: Leiden University dissertation.

Nikolaeva, Irina 2007. Introduction. In Irina Nikolaeva (ed.), Finiteness: Theoretical and empirical foundations, 1-19. Oxford: University Press.

Noonan, Michael. 1997. Versatile nominalizations. In Joan Bybee, John Haiman \& Sandra Thompson (eds.), Essays on language function and language type: In honor of Talmy Givón, 373-394. Amsterdam \& Philadelphia: John Benjamins.

Orlov, A. M. 1873. Grammatika man'čžurskogo jazyka. St. Petersburg: Nauk. 
Polivanov, Evgenij Dmitrvič 1924. K rabote o muzykal'noj akcentuacii v japonskom jazyke (v svjazi s malajskim) [Research on the musical accentuation of Japanese (with reference to Malay)]. Bjulleten' 1-go Sredne-Aziatskogo gosudarstvennogo universiteta [Bulletin of the Asian State University] 4. 101-108.

Poppe, Nicholas. 1954. Grammar of written Mongolian. Wiesbaden: Otto Harrassowitz.

Poppe, Nicholas. 1955. Introduction to Mongolian comparative studies. (Mémoires de la société Finno-Ougrienne 110.) Helsinki: Suomalais-Ugrilainen Seura.

Robbeets, Martine. 2005. Is Japanese related to Korean, Tungusic, Mongolic and Turkic? (Turcologica 64.) Wiesbaden: Harrassowitz.

Robbeets, Martine. 2013. Genealogically motivated grammaticalization. In Martine Robbeets \& Hubert Cuyckens (eds.), Shared grammaticalization with special focus on the Transeurasian languages (Studies in Language Companion Series 132), 147-175. Amsterdam \& Philadelphia: John Benjamins.

Robbeets, Martine 2015. Diachrony of verb morphology. Japanese and the Transeurasian languages. (Trends in Linguistics 291). Berlin \& Boston: De Gruyter Mouton.

Sapir, Edward. 1921. Language. New York: Harcourt, Brace \& World.

Sárközi, Alice. 2004. Classical Mongolian. Munich: LINCOM.

Street, John. 1957. The language of the secret history of the Mongols. New Haven, CT: American Oriental Society.

Trask, Robert Lawrence. 1993. A dictionary of grammatical terms in linguistics. London: Routledge. Vovin, Alexander. 1994. Genetic affiliation of Japanese and methodology of linguistic comparison. Journal de la Société finno-ougrienne 85. 241-256.

Vovin, Alexander. 2008. Proto-Japanese beyond the accent system. In Bjarke Frellesvig \& John Whitman (eds.) Proto-Japanese: Issues and prospects. (Current Issues in Linguistic Theory 294), 141-156. Amsterdam \& Philadelphia: Benjamins.

Vovin, Alexander. 2009. A descriptive and comparative grammar of Western Old Japanese, part 2: Adjectives, verbs, adverbs, conjunctions, particles, postpositions. (Languages of Asia 8.) Folkestone: Global Oriental.

Weiers, Michael. 1966. Untersuchungen zu einer historischen Grammatik des präklassischen Schriftmongolisch. Bonn: Rheinischen Friedrich-Wilhelms-Universität dissertation.

Werner, Heinrich. 1997. Die ketische Sprache. Wiesbaden: Harrassowitz.

Wrona, Janick. 2008. The nominal and adnominal forms in Old Japanese: Consequences for a reconstruction of pre-Old Japanese syntax. In Bjarke Frellesvig \& John Whitman (eds.), Proto-Japanese: Issues and prospects (Current Issues in Linguistic Theory 294), 193-215. Amsterdam \& Philadelphia: John Benjamins.

Wrona, Janick. 2011. A case of non-derived stand-alone nominalization: Evidence from Japanese. In Foong Ha Yap, Karen Grunow-Harsta \& Janick Wrona (eds.), Nominalization in Asian languages (Typological Studies in Language 96), 423-443. Amsterdam \& Philadelphia: John Benjamins.

Yap, Foong Ha \& Stephen. Matthews 2008. The development of nominalizers in East Asian and Tibeto-Burman languages. In María José López-Couso \& Elena Seoane (eds.), Rethinking grammaticalization: New perspectives (Typological Studies in Linguistics 76), 309-341. Amsterdam \& Philadelphia: John Benjamins.

Yap, Foong Ha, Stephen Matthews \& Kaoru Horie. 2004. From pronominalizer to pragmatic marker: Implications for unidirectionality from a crosslinguistic perspective. In Olga Fischer, Muriel Norde \& Harry Perridon (eds.) Up and down the cline: The nature of grammaticalization (Typological Studies in Language 59), 137-168. Amsterdam \& Philadelphia: John Benjamins. 


\section{Appendix. Abbreviations}

\section{a. linguistic terms}

\begin{tabular}{ll} 
ACC & accusative \\
ABL & ablative \\
ADN & adnominalizer \\
ADV & adverbializer \\
ART & article \\
CAUS & causative \\
COND & conditional \\
CONV & converb \\
COP & copula \\
DAT & dative \\
DEF & finite \\
DEP & dependency marker \\
EMO & emotive \\
F & feminine \\
FIN & finite \\
FOC & focus \\
FUT & future \\
GEN & genitive \\
INF & infinitive \\
INST & instrumental \\
IPF & imperfective \\
LOC & locative \\
MOD & modulator \\
NEG & negative \\
NML & nominalizer \\
PASS & passive \\
PCP & participle \\
PERF & perfect \\
PF & perfective \\
PL & plural \\
POSS & possessive \\
POT & potential \\
PROX & proximal \\
PST & past \\
PT & particle \\
Q & question marker \\
REFL & reflexive \\
SG & singular \\
SUSP & suspective \\
TOP & topic \\
VOC & vocative \\
& \\
\hline
\end{tabular}




\section{b. languages}

$\begin{array}{ll}\text { EMJ } & \text { Early Middle Japanese } \\ \text { Evk. } & \text { Evenki } \\ \text { Ma. } & \text { Manchu } \\ \text { MK } & \text { Middle Korean } \\ \text { MMo. } & \text { Middle Mongolian } \\ \text { Na. } & \text { Nanai } \\ \text { OJ } & \text { Old Japanese } \\ \text { OTk. } & \text { Old Turkic } \\ \text { pA } & \text { Proto-Altaic } \\ \text { pJ } & \text { Proto-Japonic } \\ \text { pJK } & \text { Proto-Japano-Koreanic } \\ \text { pK } & \text { Proto-Koreanic } \\ \text { pMo } & \text { Proto-Mongolic } \\ \text { pTEA } & \text { Proto-Transeurasian } \\ \text { pTg } & \text { Proto-Tungusic } \\ \text { pTk } & \text { Proto-Turkic } \\ \text { Ud. } & \text { Udehe } \\ \text { WMo. } & \text { Written Mongolian } \\ \text { WOJ } & \text { Western Old Japanese }\end{array}$

\section{c. primary sources}

$\begin{array}{ll}\text { HY } & \text { 1389 Hua-yi Yiyu } \\ \text { K } & \text { 712 Kojiki } \\ \text { Kumkang } & \text { 1464 Kumkang panya phalamil kyeng enhay } \\ \text { MYS } & \text { ca. } 759 \text { Man'yōshū } \\ \text { NK } & \text { 720 Nihonshoki kayō } \\ \text { Pak } & 1517 \text { Pak thongsa enhay } \\ \text { SH } & \text { 1241 Secret History } \\ \text { SK } & \text { Sidi kur } \\ \text { SM } & \text { 600-800 Senmyō } \\ \text { Twusi } & \text { 1481 Twusi enhay } \\ \text { Wel } & \text { 1459 Welin sekpo }\end{array}$

